\title{
O VALOR DO AMANHÃ: ENSAIO SOBRE A NATUREZA DOS JUROS
}

\author{
Resenha do livro $O$ valor do amanhã: ensaio sobre a natureza dos juros, \\ de Eduardo Giannetti*
}

São Paulo: Companhia das Letras, 2005

\section{Paula Meyer Soares Passanezi ${ }^{* *}$}

O que são juros? Por que eles existem? Giannetti, em linguagem clara e direta, explica por meio de exemplos na natureza e no cotidiano das pessoas a real natureza deles.

$\mathrm{Na}$ verdade, a valoração do amanhã tem um preço. Esse preço decorre sobretudo da escolhas que fazemos, uma vez que "O presente foge, o passado é irrecobrável e o futuro incerto” (p. 67). A incerteza do que ocorrerá no futuro permeia a mente humana incessantemente e, de certo modo, a dos animais (não de modo consciente). Ademais, a sobrevivência e permanência na Terra obedece a um ciclo - juventude, maturidade e velhice. Isso leva à adoção inevitável de escolhas dentro de um espaço de tempo em troca do usufruto de alguns benefícios no momento presente. Esse trade-off entre o momento presente e o futuro imputa a idéia de trocas intertemporais - são ações para manipular de alguma forma a seqüência de eventos no tempo de modo a favorecer a realização e um dado fim (p. 69). O organismo humano, por exemplo, sabe que envelhecerá e que a reprodução das células diminuirá mais cedo ou mais tarde. Nesse sentido, é necessário antever esse episódio e permitir a reprodução até determinado período em que o organismo esteja apto a gerar um novo ser. A mudança das estações do ano, por exemplo, mostra claramente esse trade-off entre armazenar energia o suficiente para atravessar os tenebrosos outono e inverno e aproveitar os primeiros raios de

\footnotetext{
* $\mathrm{PhD}$ em Economia pela Universidade de Cambridge e autor de numerosos artigos e livros.

* Coordenadora do curso de Ciências Econômicas, doutora em Economia de Empresas pela FGVEAESP.
} 
sol com a chegada da primavera. A queda das folhas na fria temporada diminui a probabilidade de perda de energia, uma vez que os canais de dissipação desta não existem temporariamente mais. Com o raiar do sol na primavera, brotos e novas folhas florescerão, permitindo novamente ao vegetal a captação de energia necessária à sobrevivência. Essas escolhas, no entanto, envolvem riscos, uma vez que não se pode antever de modo seguro o futuro. Então nos resta apenas indagar: desfrutar o momento ou cuidar do amanhã?

Eduardo Giannetti, nascido em Belo Horizonte e PhD em Economia pela Universidade de Cambridge, autor de numerosos artigos e livros, entre eles Auto-engano e Felicidade (ambos publicados pela Companhia da Letras), apresenta com muita propriedade a bendita natureza dos juros na mente humana e na dos animais (se assim posso dizer).

A obra $O$ valor do amanhã divide-se em quatro partes. Na primeira, Gianneti busca na biologia a explicação e a origem da natureza dos juros. $\mathrm{O}$ autor discute a questão da paciência tanto no aspecto comportamental quanto no da fisiologia humana. O armazenamento de gordura no corpo humano é uma precaução do organismo em possíveis períodos futuros de inanição! O metabolismo é o gerenciador de energia durante esses períodos. A reprodução das mariposas é um jogo árduo de amor e ódio, ou melhor, uma explosão de amor que não pode ser adiada. A dor e o prazer estão em pauta, e a primeira não pode ser adiada em detrimento de uma intensa sensação de prazer momentâneo. Escolhas extremas geram resultados patéticos — no caso da reprodução das mariposas —, apenas um sobrevive para dar vazão à prole que virá no futuro.

$\mathrm{Na}$ segunda parte, o autor mostra a finitude da permanência humana e animal na Terra. A consciência dessa limitação remete à adoção de escolhas dentro de uma linha de tempo. A caça dos leopardos africanos por animais selvagens mostra a clara disposição destes em preferir o usufruto de refeições rápidas e apetitosas à busca por animais de menor porte e menos atraentes. O desejo árduo em desfrutar tão logo a presa ignora o risco de ser morto na ação de captura do animal. Essa incapcidade de esperar decorre simplesmente da noção clara da finitude da vida e da necessidade de saciar o desejo intenso - no caso, a fome.

A terceira parte analisa o processo de formação de crenças em relação ao futuro e em diferentes esferas da vida prática, e aponta algumas das princi- 
pais ilusões de ótica, estratégias e implementação no cotidiano. Apesar da finitude da vida, a incerteza com relação ao futuro permanece. Até que ponto sabemos ponderar entre o peso que damos ao presente e ao futuro? É sabido que em algumas situações é possível antever onde se deseja estar ou qual a sensação que se deseja desfrutar em um período futuro próximo. É natural que um professor reserve um tempo para escrever um livro, que haja tolerância para a finalização de uma determinada atividade. No entanto, existem algumas anomalias de antevisão. As expectativas paternas com relação à sua prole podem ser frustradas, uma vez que nesse tempo (mínimo de 20 anos até a chegada da idade adulta) as escolhas adotadas pelos filhos podem não alcançar o que os seus pais esperam. A estratégia em jogar incessantemente em loterias pode não alcançar o seu target — tornar-se rico da noite para o dia. Tal estratégia pode ser frustrada, uma vez que a probabilidade de o seu bilhete ser o premiado pode ser mínima ou máxima! Isso não sabemos dizer, pois não podemos prever o que irá acontecer.

A quarta parte mostra que a natureza impõe limites. O prazer e a dor atam-se. É necessário fazer escolhas, e somente o preço que estamos dispostos a pagar é que configurará a escolha. Quanto menor a tolerância de espera para o usufruto da escolha maior será o preço a ser pago no presente, caso contrário, aquele que sabe esperar será premiado. Essa é uma ponderação eterna que homens e animais fazem. E, por que não dizer, cada um sabe realmente o verdadeiro valor do amanhã. 